Aleksandar Grujić1, ${ }^{1,}$, Jasna Stajić-Trošić ${ }^{1}$, Mirko Z. Stijepović2 Srđan Perišić ${ }^{3}$, Tomáš Žák ${ }^{4}$

${ }^{1}$ University of Belgrade, Institute of Chemistry, Technology and Metallurgy, Belgrade, Serbia, ${ }^{2}$ University of Belgrade, Faculty of Technology and Metallurgy, Belgrade, Serbia, ${ }^{3}$ University of Belgrade, Innovation Center, Faculty of Technology and Metallurgy, Belgrade, Serbia, ${ }^{4}$ Institute of Physics of Materials AS CR, Brno, Czech Republic

Scientific paper ISSN 0351-9465, E-ISSN 2466-2585 UDC:620.172.22:537.622.4 doi: $10.5937 /$ ZasMat $1704570 \mathrm{G}$

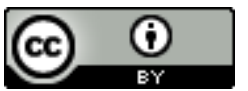

Zastita Materijala 58 (4) 570 - 575 (2017)

\title{
Tensile strength properties of hybrid magnetic composite materials
}

\begin{abstract}
The Nd-Fe-B-barium ferrite hybrid composite materials with epoxy matrix presented in this paper cover maximum energy product from 1 to 13 MGOe. Mixture of magnetic particles is responsible for high magnetic quality, while the thermosetting resin plays a role in mechanical properties. Samples with various ratio of $\mathrm{Nd}-\mathrm{Fe}-\mathrm{B}$ to barium ferrite in constant weight of epoxy resin are examined by tensile strength measurements. Magnetic measurements carried out by using vibrating sample magnetometer (VSM) show typical hysteresis loop. A structural analysis of composite surface is conducted by scanning electron microscope (SEM). Uniform particle distribution of plate shape $\mathrm{Nd}-\mathrm{Fe}-\mathrm{B}$ particles and spherical barium ferrite agglomerates is essential for both, mechanical and magnetic properties of composite materials. Fine particles are incorporated in-between larger particles in epoxy bulk which lead to improving the properties.

Keywords: $\mathrm{Nd}-\mathrm{Fe}-\mathrm{B}$, ferrite, bonded magnets, composite, tensile strength.
\end{abstract}

\section{INTRODUCTION}

Polymer bonded magnets (PBMs) are widely used in many industrial branches, home devices and daily life [1]. Various magnetic medium and different types of polymer matrices give broad opportunity to produce PBMs with requested properties. In recent years, high demand for miniaturization of IT products, such as smart phones and tablets, makes $\mathrm{Nd}-\mathrm{Fe}-\mathrm{B}$ bonded magnets very applicable component with great expanse of production [2]. As a very suitable magnetic material with superior magnetic properties, $\mathrm{Nd}-\mathrm{Fe}-\mathrm{B}$ bonded magnets become the focus of many research groups [3-5].

Various problems at the world level in the exploitation of the basic ore, spatial techniques of $\mathrm{Nd}-\mathrm{Fe}-\mathrm{B}$ production and high sensitivity on oxidation make $\mathrm{Nd}-\mathrm{Fe}-\mathrm{B}$ material expensive. On the other side, ferrites are still most widespread magnetic material even with lower magnetic properties compared to Nd-Fe-B. An affordable price and easy to use as well as good magnetic properties

\footnotetext{
${ }^{*}$ Corresponding author: Aleksandar Grujič

E-mail: gruja@tmf.bg.ac.rs

Paper received: 21. 09. 2019.

Paper accepted: 16. 10. 2017.

Paper is available on the website: www.idk.org.rs/journal
}

are the main advantages of ferrite material. Recent research activities are oriented towards the substitution of a part of Nd-Fe-B with ferrite [1]. The advantages of the hybrid type of bonded magnets are upgraded mechanical properties, acceptable magnetic properties and cost production reduction.

The amounts of magnetic medium in polymer matrix, type, shape and size of particles have a direct impact on microstructure and magnetic properties of PBM [6]. Physical and thermal properties of polymer are essential for mechanical properties and potential application of composites. Optimal balance between two main components, polymer and magnetic particles, is crucial for final properties of the composites [7].

In this study, hybrid magnetic polymer composites are synthesized using $\mathrm{Nd}-\mathrm{Fe}-\mathrm{B}$, barium ferrite and epoxy resin. Two types of magnetic particles are mixed in different ratio and then mixed with epoxy resin. Structural properties, tensile strength properties and magnetic behavior are examined and discussed.

\section{EXPERIMENTAL PROCEDURE}

Angular plate shape $\mathrm{Nd}-\mathrm{Fe}-\mathrm{B}$ magnetic particles and barium ferrite agglomerates are used as a functional magnetic medium for polymer bonded magnetic materials production. The magnetic properties and chemical composition of starting magnetic materials are presented in Table 1. 
Table 1. Magnetic properties and chemical composition of magnetic particles

Tabela 1. Magnetna svojstva i hemijski sastav magnetnih čestica

\begin{tabular}{|c|c|c|c|c|}
\hline & $B_{r},(\mathrm{kG})$ & $H_{c b},(\mathrm{kOe})$ & $H_{c j},(\mathrm{kOe})$ & $(B H)_{\max },(\mathrm{MGOe})$ \\
\hline \multirow[t]{2}{*}{$\mathrm{Nd}-\mathrm{Fe}-\mathrm{B}$} & 8.2 & 6.1 & 8.7 & 13.1 \\
\hline & \multicolumn{4}{|c|}{ Nd: 21-25 wt.\%, Co: 3-5 wt.\%, B < 1.5 wt.\%, Zr: 3-5 wt.\%, Fe: balance } \\
\hline \multirow[t]{2}{*}{ Barium ferrite } & 2.3 & 1.9 & 3.6 & 1.3 \\
\hline & \multicolumn{4}{|c|}{$\mathrm{BaFe}_{12} \mathrm{O}_{19}: \approx 99$ wt. $\%$} \\
\hline
\end{tabular}

Utilized thermosetting epoxy resin is liquid mixture of Bisphenol A and Bisphenol F components and cross-linking chemical additive which cures fully at room temperature. The physical properties of applied epoxy resin are: tensile strength $58 \mathrm{MPa}$, elongation $2.8 \%$, compression strength $96 \mathrm{MPa}$, flexural strength $78 \mathrm{MPa}$, and density $1.2 \mathrm{~g} / \mathrm{cm}^{3}$.
Samples are prepared by compression molding technique. Composite materials with various ratio of $\mathrm{Nd}-\mathrm{Fe}-\mathrm{B}$ to barium ferrite in $10 \mathrm{wt} \%$ of epoxy matrix are compressed into bell shape samples for tensile strength testing (Fig. 1a). The dimensions of samples are presented in Fig. $1 \mathrm{~b}$ according to ASTM D 3039-00 [8].

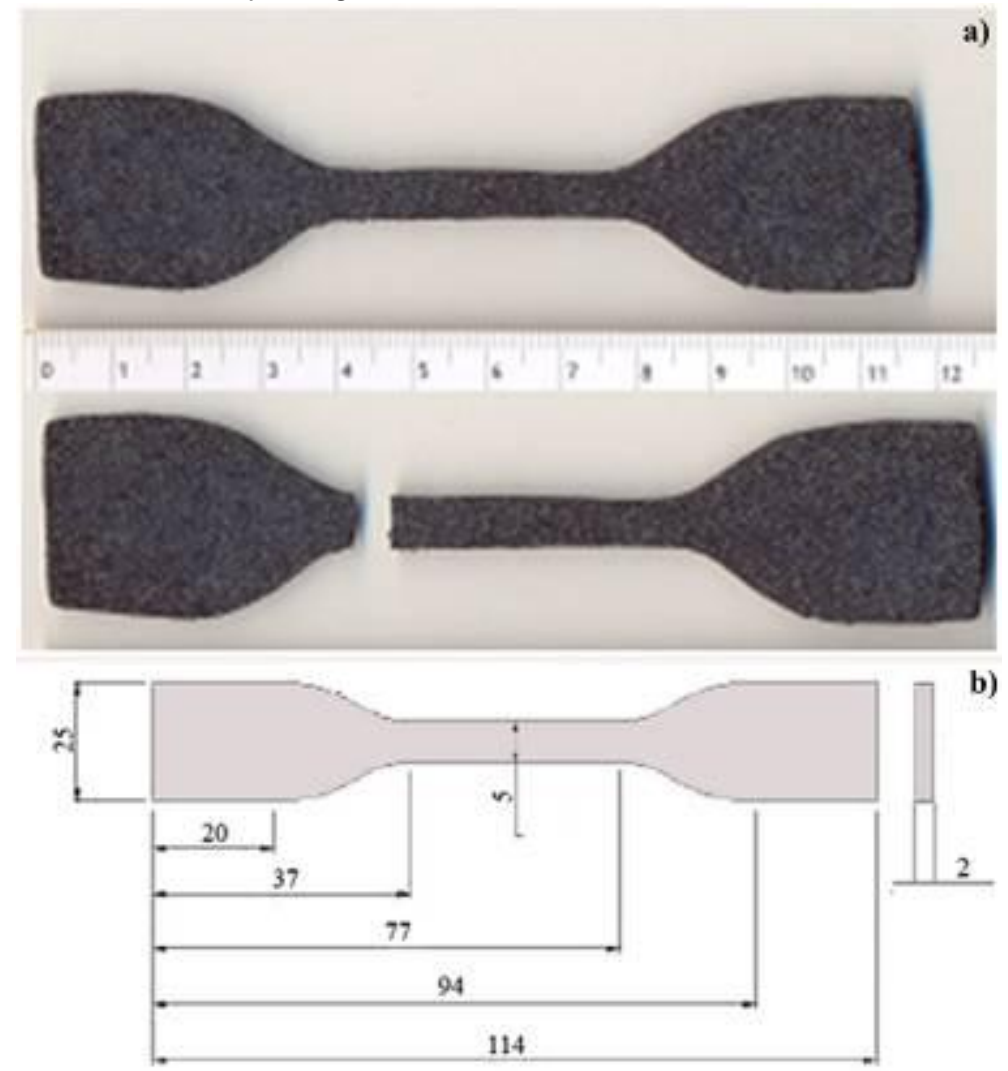

Figure 1. a) Bell shaped specimen for tensile strength testing and b) Schematic presentation of dimensions of specimen

Slika 1. a) Uzorak oblika zvona za ispitivanje zatezne čvrstoće, i b) Shematski prikaz dimenzija uzorka

The tensile strength measurements are performed using lab scale Motorized Force Test Systems ESM301LE with maximal force up to $1.5 \mathrm{kN}$.

The microstructures of specimen surfaces are observed by a JEOL JSM-5800 scanning electron micro-scope (SEM), with an accelerating voltage of $20 \mathrm{kV}$. Sample surfaces were sputtered with gold using a POLARON SC 502 sputter coater for enhanced conductivity.
The magnetic properties were obtained using vibrating sample magnetometer (VSM) (EG\&G Princeton Applied Research type) at ambient temperature $(300 \mathrm{~K})$. The vector of magnetic field was parallel to disc shape specimen. Maximum magnetic field strength was $2.4 \mathrm{~T}$ and time of exposure was $10 \mathrm{~s}$. 


\section{RESULTS AND DISCUSSION}

The SEM micrographs of composite surface are presented in Fig. 2. Larger angular plate shape particles correspond to $\mathrm{Nd}-\mathrm{Fe}-\mathrm{B}$ (marked as "A") while the small spherical particles are barium ferrite (marked as "B"). Smoot surfaces and dark grey parts belong to the epoxy resin (marked as "C"). Epoxy fills in the finest pores between particles and has a role to bond the particles. Beside the epoxy resin, the smallest particles also fill in the space between large particles (marked as "D"). This structure has direct influence on mechanical properties of final composite material, similar to one in the literature [9]. Uniform particle distribution, good adhesion between particle to particle and particle to epoxy resin have great impact on microstructure and consequently on mechanical and magnetic properties.

Tensile strength tests are conducted for hybrid composite materials in a function of magnetic particles content (for both, Nd-Fe-B and barium ferrite) in 10 wt.\% of epoxy matrix. The results are presented in Figs. 3 to 5 . All curves are polynomial fitted.

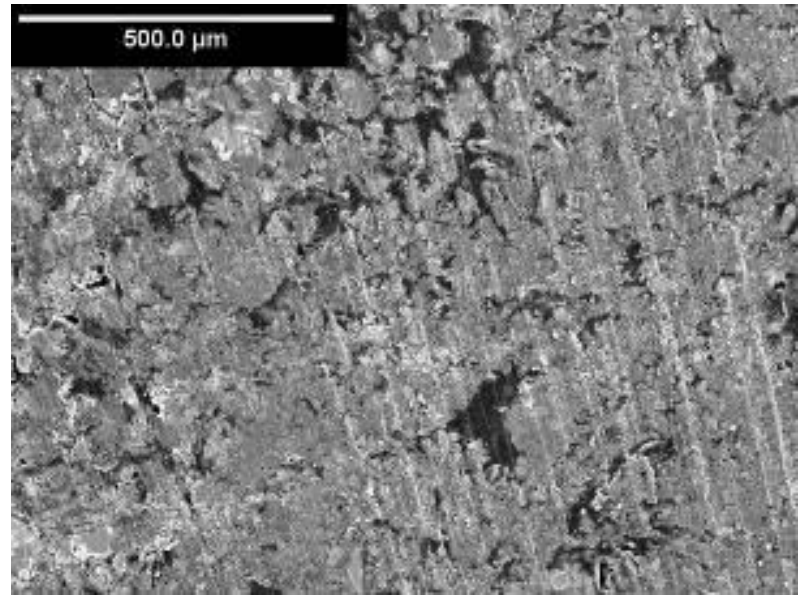

Figure 2. SEM micrographs of $\mathrm{Nd}-\mathrm{Fe}-\mathrm{B}$-barium ferrite epoxy composite materials ("A" - Nd-Fe-B particles, " $B$ " - barium ferrite agglomerates, " $C$ " epoxy resin, " $D$ " - smallest particles between large particles and epoxy resin)

Slika 2. SEM slike Nd-Fe-B-barijum ferit - epoksi kompozitnih materijala

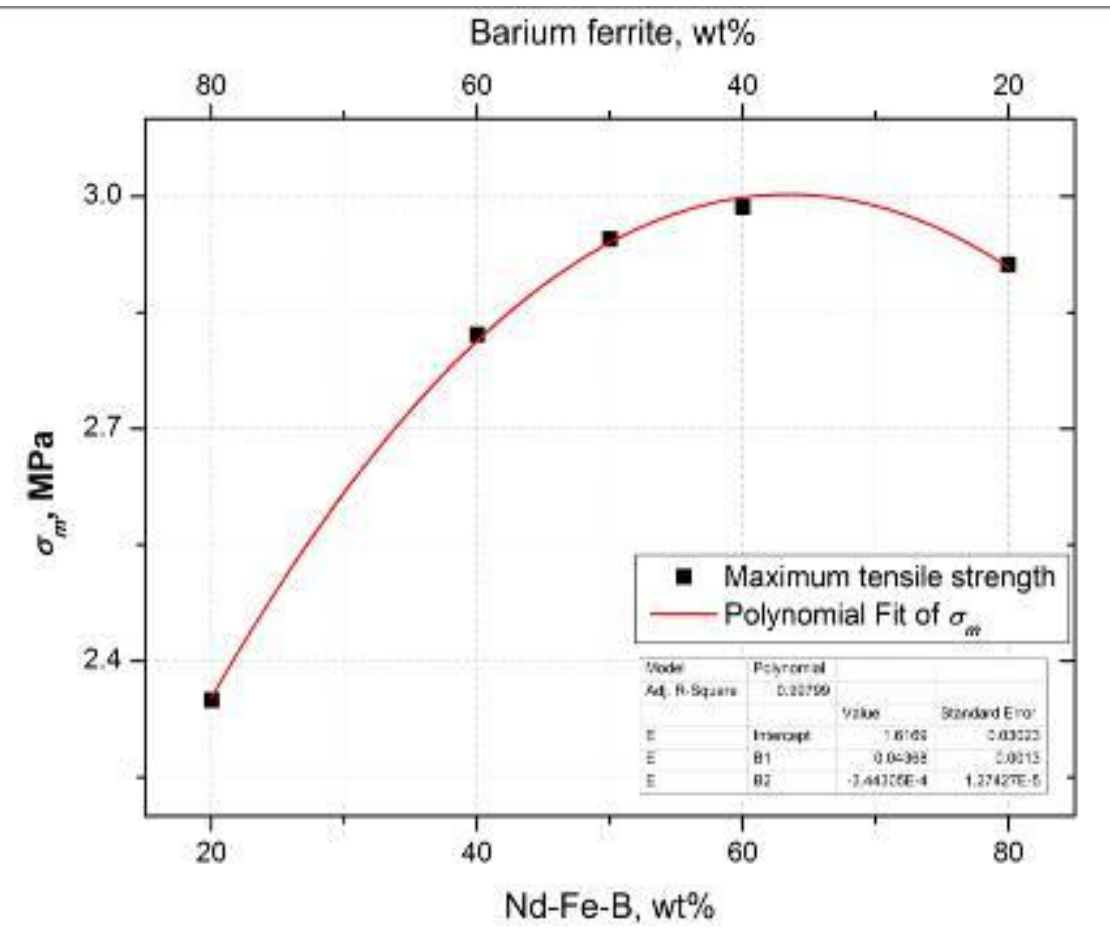

Figure 3 . The maximum stress in the function of magnetic medium content in composite materials with $10 \mathrm{wt}$ \% of epoxy resin

Slika 3. Maksimalni napon u funkciji od udela magnetnog medijuma za kompozitne materijale sa 10 mas \% epoksi veziva

Figure 3. shows behavior of maximal values of stress vs. contents of magnetic $\mathrm{Nd}-\mathrm{Fe}-\mathrm{B}$ and barium ferrite fillers. The pick of the curve is around $3 \mathrm{MPa}$ and correspond to $\mathrm{Nd}-\mathrm{Fe}-\mathrm{B}$ to barium ferrite ratio $63: 37$ wt.\%. Figure 4 . shows the values of maximal elongation in the function of $\mathrm{Nd}-\mathrm{Fe}-\mathrm{B}$ and barium ferrite content in composite materials with 10 wt.\% of epoxy resin. These are the values whereby maximum stress is achieved, before the sample breaks. There is small difference between $\varepsilon$ values i.e. all values of deformation are in the range of $0.5 \%$. 


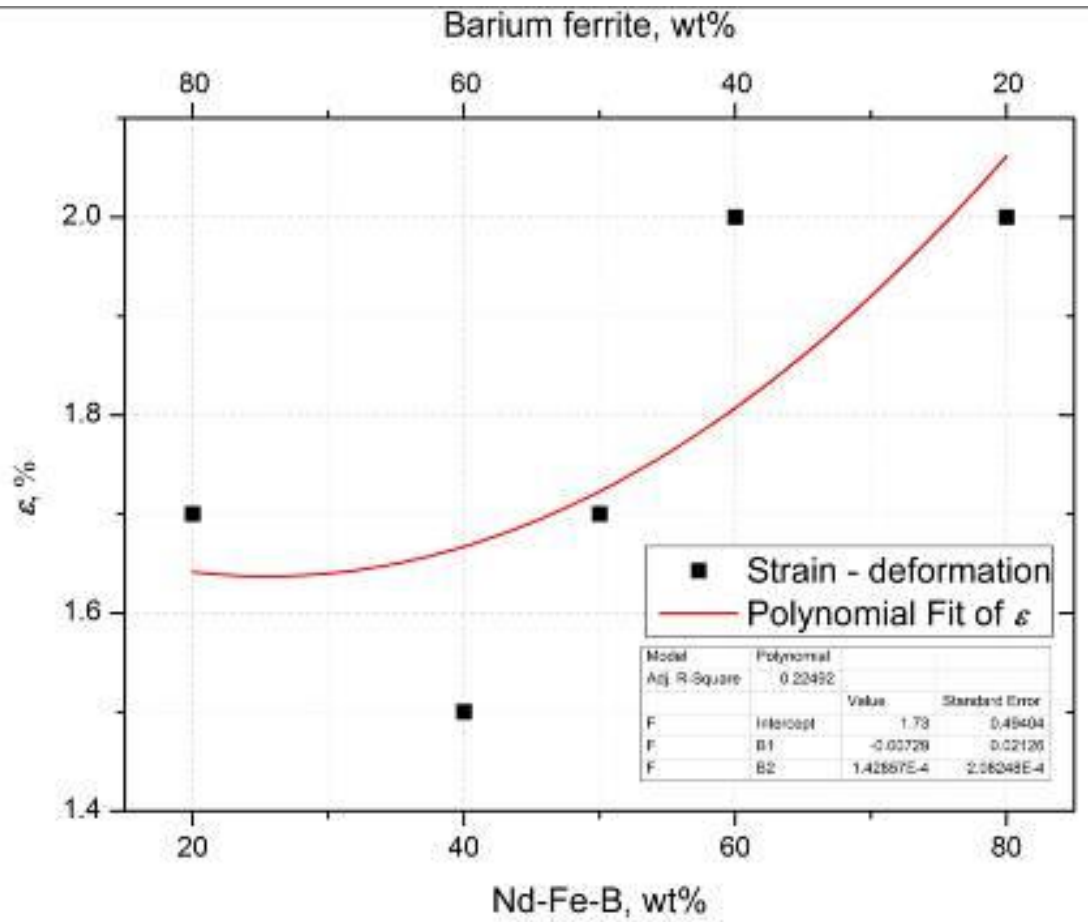

Figure 4. Deformation at the maximum stress in the function of magnetic medium content in composite materials with 10 wt.\% of epoxy resin

Slika 4. Deformacija pri maksimalnom naponu u funkciji od udela magnetnog medijuma za kompozitne materijale sa 10 mas \% epoksi veziva

The change of modulus of elasticity $\Delta E$ in the function of magnetic medium content is presented in Fig. 5.

The modulus of elasticity $E$ is calculated from sigma-stress plot obtained by testing device as a tangent on started slope of the curve [10]. The modulus of elasticity of investigated samples is calculated using eq.1 [8]:

$$
E=\frac{\Delta \sigma}{\Delta \varepsilon}=\frac{\Delta F}{\Delta \varepsilon} \cdot \frac{1}{b \cdot d}
$$

Whereas: $b, d$-geometry of the specimen, $\Delta F-$ change of applied force, $\sigma$-stress, $\varepsilon-$ strain. $\sigma /$ is determined by linear regression method from straight parts of stress-strain curve i.e. in the region under the Hooks law.

The curve of modulus of elasticity vs. Nd-Fe-B (barium ferrite) content presented in Fig. 5 shows exponential growth with increasing content of $\mathrm{Nd}$ $\mathrm{Fe}-\mathrm{B}$ (and consequently decreasing content of barium ferrite). The pick of the curve is around 70 wt.\% of $\mathrm{Nd}-\mathrm{Fe}-\mathrm{B}$, subsequently values of $E$ decreases. The main reason for this behavior lies in microstructure of the composites. As previously discussed, the barium ferrite agglomerates are crowned and small spherical particles fill in the pores between plate shapes $\mathrm{Nd}-\mathrm{Fe}-\mathrm{B}$ particles. Also, Nd-Fe-B particles are angular and brittle, and during mixing stage of production small particles fill in the space between larger particles. Obviously, weight amount ratio of 70:30 (Nd-Fe-B : barium ferrite) shows the best configuration of small and large particles of both $\mathrm{Nd}-\mathrm{Fe}-\mathrm{B}$ and barium ferrite in $10 \mathrm{wt} \%$ of epoxy matrix.

Taking previous analysis of mechanical properties into consideration, the magnetic properties of sample with 100 wt.\% of $\mathrm{Nd}-\mathrm{Fe}-\mathrm{B}$, 100 wt.\% of barium ferrite and 50:50 combine of $\mathrm{Nd}-\mathrm{Fe}-\mathrm{B}$ and barium ferrite are compared and discussed. Hysteresis loops of barium ferrite, $\mathrm{Nd}$ $\mathrm{Fe}-\mathrm{B}$ and hybrid $\mathrm{Nd}-\mathrm{Fe}-\mathrm{B}-$ barium ferrite in $10 \mathrm{wt} . \%$ of epoxy resin are presented in Fig. 6. Nd-Fe-B sample show the highest remanence and the highest coercivity, but magnetic saturation is not achieved due to low magnetic field $(20 \mathrm{kOe})$ for this type of magnetic materials. In other hand, barium ferrite hysteresis loop show full magnetic saturation. Remanence is around $15 \mathrm{emu} / \mathrm{g}$ while the coercivity is around $4 \mathrm{kOe}$. Between these two hysteresis loops lie hybrid $\mathrm{Nd}-\mathrm{Fe}$-B-barium ferrite with characteristic shape. Remanence, coercivity and magnetic saturation of hybrid magnetic composite are $32 \mathrm{emu} / \mathrm{g}, 4 \mathrm{kOe}, 50 \mathrm{emu} / \mathrm{g}$, respectively. Different amount of particles induces different values and shape of hysteresis loops, as reported previously [11]. 


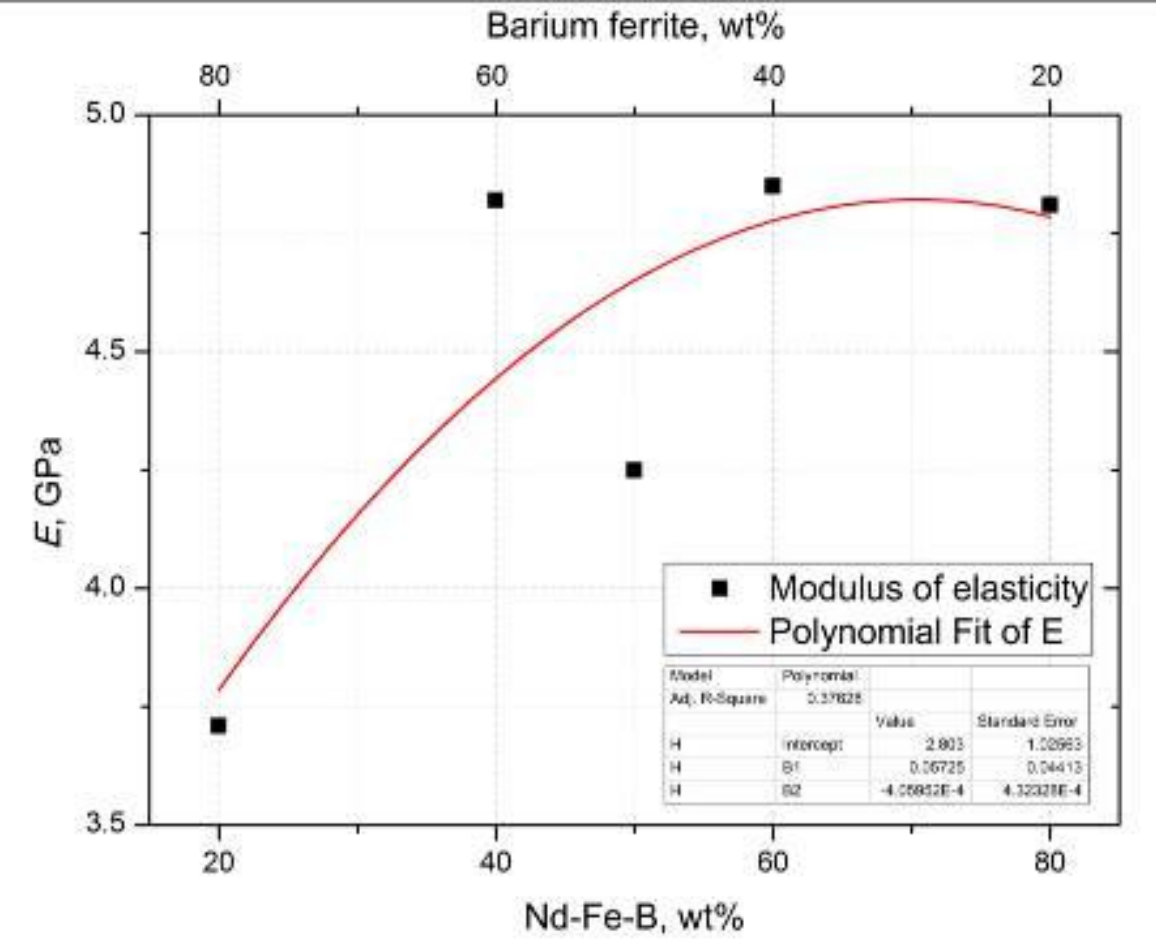

Figure 5. The modulus of elasticity in the function of magnetic medium content in composite materials with 10 wt.\% of epoxy resin

Slika 5. Modul elastičnosti u funkciji od udela magnetnog medijuma za kompozitne materijale sa 10 mas \% epoksi veziva

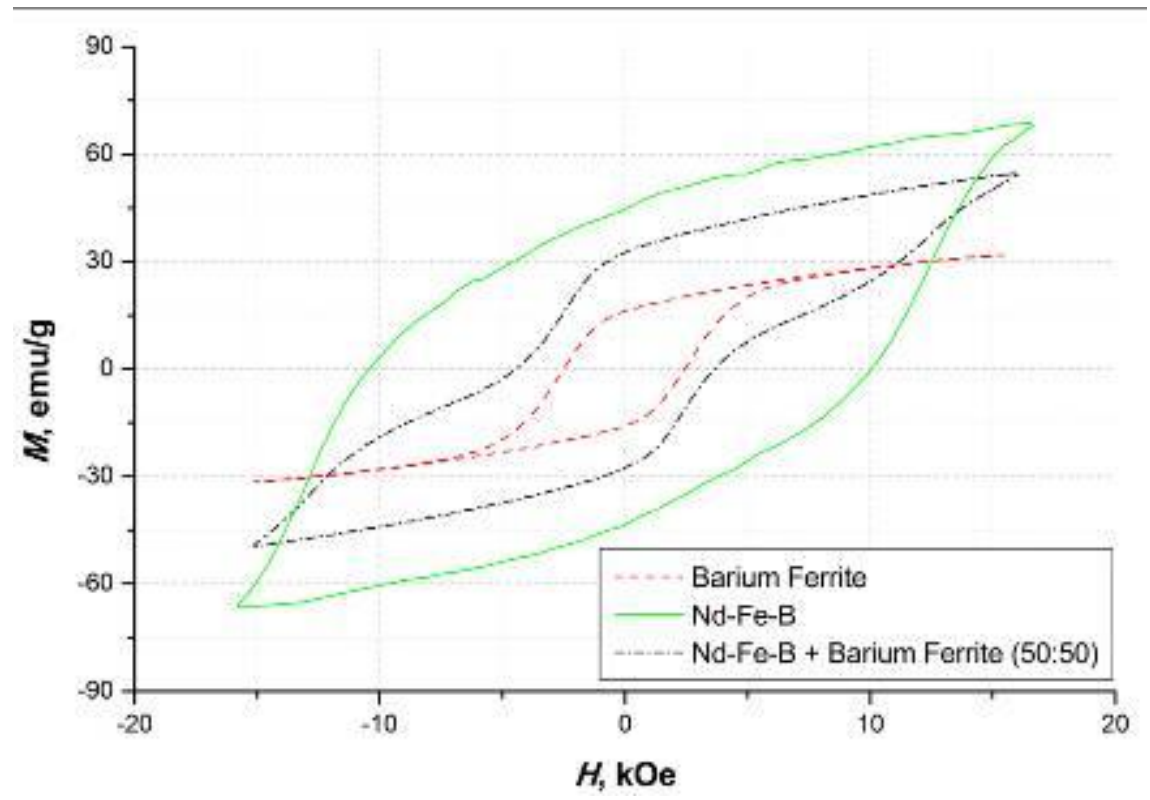

Figure 6. Hysteresis loops of magnetic composite materials

Slika 6. Histerezisna petlja magnetnih kompozitnih materijala

For proposed application it is essential to determine optimal ratio between used magnetic fillers as well as weight amount of epoxy resin. The content of $10 \mathrm{wt} \%$ of epoxy resin has been selected on experimental experience during previous research activities $[5,7,10,11]$.

\section{CONCLUSION}

The amount and type of magnetic particles have direct impact on magnetic behavior of composites. The hysteresis loop of hybrid composites lies between $\mathrm{Nd}-\mathrm{Fe}-\mathrm{B}$ and barium ferrite. Epoxy polymer matrix is responsible for mechanical 
properties, however ratio of different particles contents also contribute to overall properties. Samples with ratio $70: 30 \mathrm{Nd}-\mathrm{Fe}-\mathrm{B}$ to barium ferrite obtained by tensile strength test shows the highest value of modulus of elasticity.

\section{Acknowledgement}

This work has been supported by the Ministry of Education, Science and Technological Development, Serbia [Projects TR34011 and III45019].

\section{REFERENCE}

[1] G.C.Hadjipanayis (2003) Bonded Magnets, Kluwer Academic Publishers, NATO Science series, London.

[2] Y.Yang, A.Walton, R.Sheridan, K.Guth (2017) REE Recovery from End-of-Life NdFeB Permanent Magnet Scrap: A Critical review, J. Sustain. Metall. 3, 122-149.

[3] L.Li, A.Tirado, I.C.Nlebedim, O.Rios, B.Post (2016) Big Area Additive Manufacturing of High Performance Bonded NdFeB Magnets, Scientific Reports, https://www.nature.com/articles/srep36212?WT. feed_name=subjects_materials-science, 31.10.2016.

[4] J.Xiao, J.Otaigbe (2000) Polymer-bonded magnets III. Effect of surface modification and particle size on the improved oxidation and corrosion resistance of magnetic rare earth fillers, J. Alloy. Compd., 309, 100-106.
[5] A.Grujić, M.Stijepović, J.Stajić-Trošić, S.Putić, D.Nedeljković, A.Stajčić, R.Aleksić (2012) Dynamic Mechanical Behaviour of Polymer Bonded Nd-Fe-B Composite Materials, Materials Transactions, 53(2), 395-400.

[6] C.Stancu, P.V.Notingher, V.Ionita, V.Marinescu, D.Panaitescu (2014) Polyethylene-based Magnetic Composites, IEEE Xplore Digital Library, pp. 1-7.

[7] A.Grujić, M.Stijepović, J.Stajić-Trošić, J.Stevanović, R.Aleksić (2011) Magnetic and Dynamic Mechanical Properties of Nd-Fe-B Composite Materials with Polymer Matrix, book Metal, Ceramic and Polymeric Composite for Various Uses (in English), Publisher InTech, Croatia, p 505-524.

[8] ASTM 3039/D 2039M00 (2000) Standard Test Method for Tensile Properties of Polymer Matrix Composite Materials, ASTM International.

[9] J.Tian, Z.Tang, Z.Zuo, D.Pan, S.Zhang (2013) Architecturing high magnetic properties of $\mathrm{NdFeB/SmFeN} \mathrm{hybrid} \mathrm{magnets,} \mathrm{Mater.} \mathrm{Lett.,} \mathrm{105,}$ 87-89.

[10] A.Grujić, V.Ćosović, N.Talijan, D.Stojanović, J. Stajić-Trošić, Z.Burzić, R.Aleksić (2010) Mechanical and Magnetic Properties of Composite Materials with Polymer Matrix, Journal of Mining and Metallurgy, B-Metall., 46(1)B, 25-32.

[11] J.Stajić-Trošić, A.Grujić, M.Z.Stijepović, D.Nedeljković, A.Stajčić , T.Zak (2014) Magnetic behaviour of hybrid magnetic composite materials, Zaštita materijala, 55(2), 170-172.

\section{IZVOD}

\section{ZATEZNA ČVRSTOĆA HIBRIDNIH MAGNETNIH KOMPOZITNIH MATERIJALA}

$U$ ovom radu proučavani su hibridni Nd-Fe-B-barijum ferit kompozitni materijali sa epoksi matricom čiji se maksimani energetski proizvod kreće od 1 do 13 MGOe. Odlična magnetna svojstva kompozita potiču od smeše magnetnih čestica, dok termoočvršćavajući polimer ima uticaj na mehanička svojstva. Uzorci sa različitim odnosom udela $\mathrm{Nd}$-Fe-B i barijum ferita u konstantnoj masi epoksi veziva su ispitivani na zateznu čvrstoću. Magnetna merenja vršena pomoću vibracionog magnetometra (VSM) pokazuju karakteristučnu histerezisnu petlju. Strukturnu analizu na površini kompozita sprovedena pomoću skenirajuće elektronske mikroskopije (SEM). Uniformna raspodela pločastih $\mathrm{Nd}-\mathrm{Fe}-\mathrm{B}$ čestica $i$ sferičnih aglomerata barijum ferita je veoma značajna i za mehanička i za magnetna svojstva kompozitnih materijala. Sitne čestice su inkorporirane između velikih čestica u masi epoksida što dovodi do poboljšanja svojstava.

Ključne reči: Nd-Fe-B, feriti, bonded magneti, kompoziti, zatezna čvrstoća.

\section{Naučni rad}

Rad primljen: 21. 09. 2017.

Rad prihvaćen: 16. 10. 2017.

Rad je dostupan na sajtu: www.idk.org.rs/casopis

(C) 2017 Authors. Published by Inženjersko društvo za koroziju. This article is an open access article distributed under the terms and conditions of the Creative Commons Attribution 4.0 International license (https://creativecommons.org/licenses/by/4.0/) 